\title{
TABANIDAE (DIPTERA) FROM THE STATE OF MARANHÃO, BRAZIL I. DESCRIPTION OF Stibasoma (Stibasoma) bella n. sp.
}

\author{
LIMEIRA-DE-OLIVEIRA, . $^{1}$ and RAFAEL, J. A. ${ }^{2}$ \\ ${ }^{1}$ Department of Chemistry and Biology, Centro de Estudos Superiores de Caxias, \\ CESC/Universidade Estadual do Maranhão, UEMA, C.P. 85, Praça Duque de Caxias, s/n, \\ Morro do Alecrim, CEP 65604-380, Caxias, MA, Brazil \\ ${ }^{2}$ Instituto Nacional de Pesquisas da Amazônia, (INPA), C. P. 478, \\ CEP 69011-970, Manaus, AM, Brazil. Fellow of the CNPq \\ Correspondence to: Francisco Limeira-de-Oliveira, Departamento de Química e Biologia, \\ Centro de Estudos Superiores de Caxias, CESC/ UEMA, C. P. 85, Praça Duque de Caxias, s/n, \\ Morro do Alecrim, CEP 65604-380, Caxias, MA, Brazil, e-mail: franciscolimeira@cesc.uema.br \\ Received October 10, 2003 - Accepted February 11, 2004 - Distributed November 30, 2005
}

(With 6 figures)

\begin{abstract}
A specimen of Stibasoma (Stibasoma) bella n. sp. collected in the municipality of Carolina is described and illustrated, representing the first record of this genus in the state of Maranhão, Brazil.
\end{abstract}

Keywords: Diptera, Maranhão, new species, Stibasoma, Tabanidae, Taxonomy.

\section{RESUMO}

\section{Tabanidae (Diptera) do estado do Maranhão, Brasil I. Descrição de Stibasoma (Stibasoma) bella sp. n.}

Um espécime de Stibasoma (Stibasoma) bella sp. n. coletado no município de Carolina é descrito e ilustrado, representando o primeiro registro do gênero no estado do Maranhão, Brasil.

Palavras-chave: Diptera, Maranhão, espécie nova, Stibasoma, Tabanidae, Taxonomia.

\section{INTRODUCTION}

The genus Stibasoma Schiner has 17 valid species, of which 14 belong to the nominal subgenus, with 11 of these recorded in Brazil, and 3 to the subgenus Stibasoma (Rhabdotylus) Lutz, with 2 recorded in Brazil (Fairchild \& Burger, 1994). Stibasoma is characterized by medium to large sized species (16 to $20 \mathrm{~mm}$ ) possessing inflated tibiae with rows of hairs, inflated palpi and sclerotized labella. Adults preferentially fly in the forest canopy (Fairchild, 1986). The subgenus Stibasoma (Stibasoma) Schiner is composed of beelike species with short antennae, a basal plate with a long dorsal spine, frequently exceeding the proximal end of the second flagellomere, and wings with varied color patterns which are never hyaline or uniformly dusky.

\section{MATERIAL AND METHODS}

The terminology and figure abbreviations used here follow MacAlpine (1981). The description was based on observations using a Wild MZ8 stereoscopic microscope (Carl Zeiss KL 1500, LDC) with an incident white light source.

The photographs of the specimen and the scale were done with a Nikon Coolpix 880 digital camera with 3.3 mega pixels, a $2.5 \mathrm{X}$ zoom, and without the use of a flash.

\section{Diagnosis}

Predominantly dark brown to black, ornamented with yellow hairs. Antennae with flagellum approximately as long as the palpi; basal plate with a long dorsal spine reaching the level of the second flagellomere. Scutum dark-brown to black with 
yellow hairs intermixed with medial and sublateral longitudinal rows of black hairs. Legs dark-brown to black with black hairs, except for white hairs on the distal end of all femora and on the proximal end of all tibiae. Tergites 1-6 with a lateral row of yellow hairs. Sternites yellow to dark-yellow.

Description. Female (Fig. 1): Length of body $17.7 \mathrm{~mm}$, wing $15.2 \mathrm{~mm}$. Frontal index 3.45 and divergence index $1.15(\mathrm{n}=1)$. Frons (Fig. 2) black with sparse dark-brown to black pruinescence and black hairs, except for yellow hairs medially visible in lateral view. Ocellar tubercle small with indistinct ocelli. Frontal callus (Fig. 2) shiny black, as wide as frons; midcallus exceeding half the height of the frons, strongly interlinked to the basal callus; subcallus dark-brown to black with gray-yellow pruinescence in dorsal view, darkyellow in lateral view. Antennae (Fig. 3) longer than the palpi, black with black hairs; scape almost three times the length of the pedicel; flagellum approximately as long as the palpi; basal plate with a long dorsal spine reaching the level of the second flagellomere; stylus (distal flagellomeres) approximately half the length of the dorsal spine on the basal plate. Face, parafacial, genae and postgenae dark-brown to black with sparse greyyellow pruinescence and black hairs, except postgenae with a mixture of black and yellow hairs. Palpi (Fig. 4) inflated, approximately as long as the flagellum, black with black hairs. Mouth parts approximately as high as the frons; labella well sclerotized. Eyes with very short sparse hairs, best visible under $50 \mathrm{x}$ magnification. Scutum (Fig. 1) dark-brown to black with sparse dark-brown pruinescence and predominantly yellow hairs, intermixed with medial and sublateral longitudinal rows of black hairs. Postpronotal lobe light-brown with a sparse light-yellow pruinescence and long sparse light-yellow and black hairs. Notopleuron light-brown to brown with yellow hairs, except for sparse black hairs on the ventral margin. Scutellum dark-brown, except for brown posterior margin with grey pruinescence and long yellow hairs intermingled with short black hairs. Mesopleuron dark-brown to black, except for light-brown anepimeron and katepimeron with black hairs and grey pruinescence visible from anterior view, and except for the anepisternum with a tuft of white to light-yellow hairs on the posterodorsal margin.
Legs dark-brown to black with black hairs, except for all femora with whitish hairs distally denser on the hind femora; all tibiae with proximal white hairs and all tarsi with reddish hairs on ventral face. Fore femora with long hairs on dorsal and posterior faces, on anterior, ventral and posterior faces of the mid-femora and on the base of all faces of hind femora, becoming shorter towards the apex and absent from the posterior face; tibiae slightly inflated with rows of black hairs on dorsal and ventral faces. Wings (Fig. 5) brown to darkbrown with hyaline apex and small hyaline areas at base, on proximal end of cell br, along vein $\mathrm{M}$ and base of vein $\mathrm{CuA}_{2}$; pterostigma dark-brown to black. Halteres light yellow, whitened at apex. Tergites (Fig. 6) dark-brown to black, black haired, except laterally with yellow to dark-yellow hairs. Tergite 1 with a small median triangle of yellow hairs; tergite 2 with sparse median yellow hairs along anterior margin. Sternites yellow to darkyellow with brown to black hairs on the median region of the first two segments and yellow on the others.

Examined material: Holotype female. Brasil, Maranhão, Carolina, Balneário Urupuxete, Isca eqüina, $07^{\circ} 23^{\prime} 54^{\prime \prime} \mathrm{S} / 47^{\circ} 15^{\prime} 00^{\prime}$ W. 10 13. xii. 2001, J. A. Rafael, F. L. Oliveira \& J. F. Vidal. Deposited at INPA (Instituto Nacional de Pesquisas da Amazônia). Right Antenna and left palpus glued on white labeling paper, right wing mounted between coverslips using balsam, both fixed to specimen pin; left wing glued to body and left flagellum lost.

Etymology: from Latin bellus $=$ beautiful.

\section{DISCUSSION}

Stibasoma bella $\mathrm{n}$. sp. differs from the other species of the nominal subgenus for its striped scutum with predominantly yellow hairs, intermixed with medial and sublateral longitudinal rows of black hairs. Sternites yellow to dark-yellow with brown to black hairs on the medial region of the first two segments and yellow on the others.

Acknowledgements - We are indebted to Dr. Inocêncio de Sousa Gorayeb for confirming the status of the new species; Roger Hutchings, M.Sc. for reviewing an early version of the manuscript; João Ferreira Vidal, technician, for his help with field collections; Márcio Cutrim M. de Castro for editing the images; and CAPES (Brazil) for granting a fellowship to the senior author. 


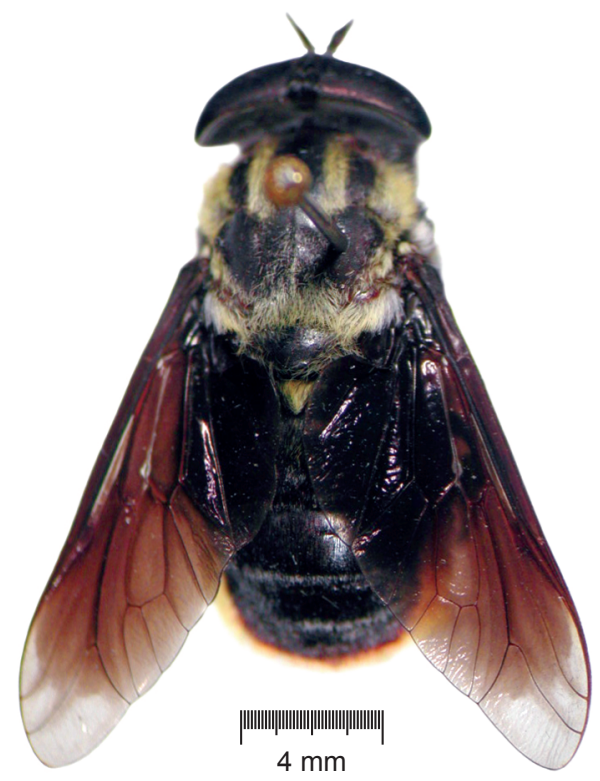

1

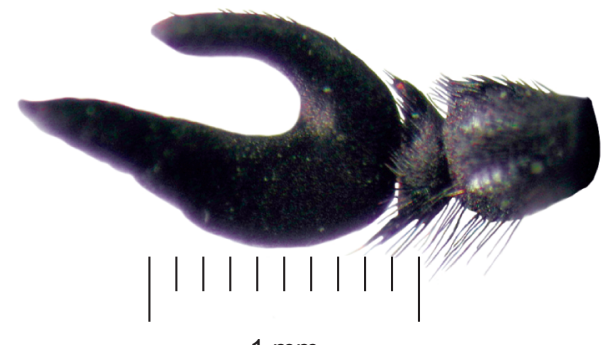

$1 \mathrm{~mm}$

3

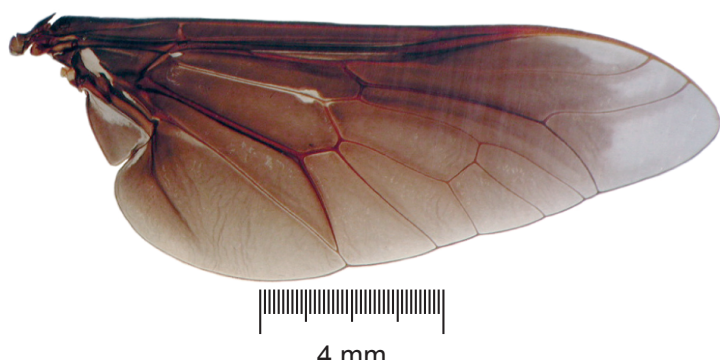

5

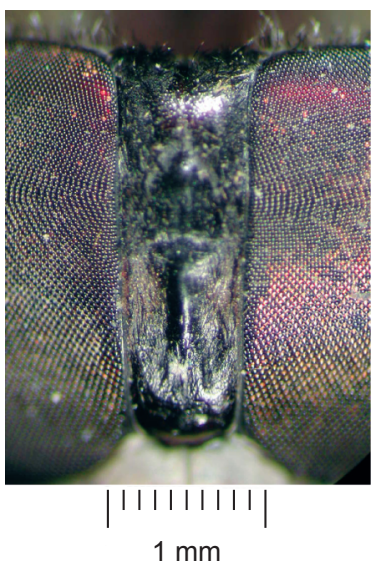

2
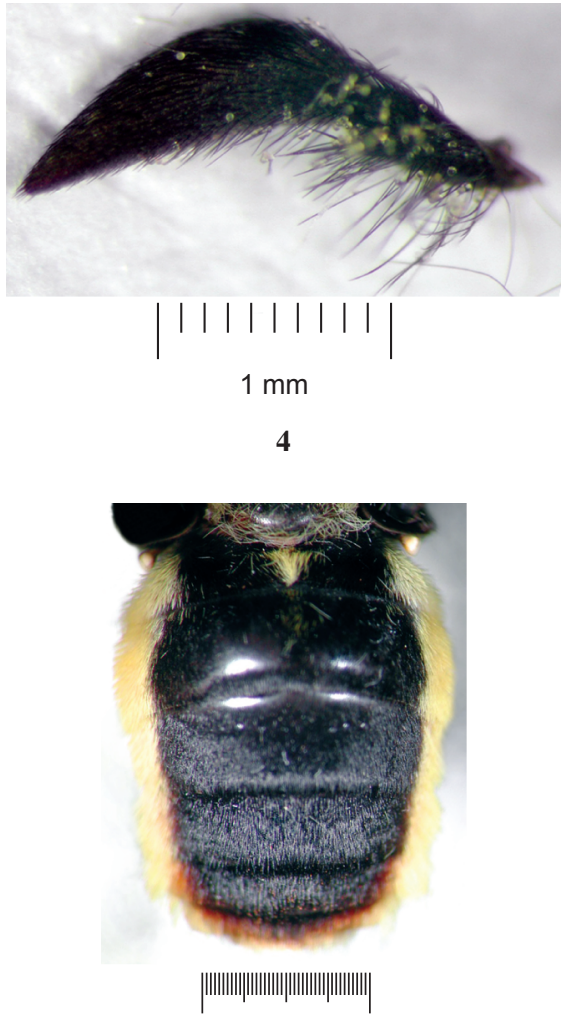

$4 \mathrm{~mm}$

Fig. 1-6 - Stibasoma bella n. sp., holotype. 1. habitus (dorsal view). 2. frons (frontal view). 3. antenna (lateral view). 4. palpi (lateral view). 5. wing (dorsal view). 6. abdomen (dorsal view). 


\section{REFERENCES}

FAIRCHILD, G. B. 1986, The Tabanidae of Panama. Contr. Amer. Ent. Inst. 22 (3): 1-139.

FAIRCHILD, G. B. \& BURGER, J. F. 1994, A Catalog of the Tabanidae (Diptera) of the Americas South of the United States. Mem. Amer. Ent. Inst., 55: 1-249.
MACALPINE, J. F. 1981, Morphology and Terminology. pp. 9-63. In: MACALPINE, J. F. et al. eds. Manual Neartic Diptera (Monograph no 27) - Volume 1, Research Branch, Agriculture, Canada. 674 pp. 